\title{
Literary Geographies
}


This page intentionally left blank 


\section{Literary Geographies}

\section{Narrative Space in Let the Great World SPIN}

Sheila Hones

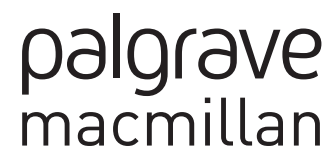




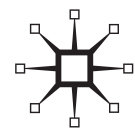

LITERARY GEOGRAPHIES

Copyright (C) Sheila Hones, 2014

Softcover reprint of the hardcover 1st edition 2014 978-1-137-41312-3

All rights reserved.

First published in 2014 by PALGRAVE MACMILLAN® in the United States—a division of St. Martin's Press LLC, 175 Fifth Avenue, New York, NY 10010.

Where this book is distributed in the UK, Europe and the rest of the world, this is by Palgrave Macmillan, a division of Macmillan Publishers Limited, registered in England, company number 785998, of Houndmills, Basingstoke, Hampshire RG21 6XS.

Palgrave Macmillan is the global academic imprint of the above companies and has companies and representatives throughout the world.

Palgrave ${ }^{\circledR}$ and Macmillan ${ }^{\circledR}$ are registered trademarks in the United States, the United Kingdom, Europe and other countries.

ISBN 978-1-349-48981-7 ISBN 978-1-137-41313-0 (eBook) DOI $10.1057 / 9781137413130$

Library of Congress Cataloging-in-Publication Data

Hones, Sheila.

Literary geographies : narrative space in Let the great world spin / Sheila Hones.

pages $\mathrm{cm}$

1. McCann, Colum, 1965- Let the great world spin. 2. Space and time in literature. 3. Narration (Rhetoric) 4. Intertextuality. I. Title.

PR6063.C335Z69 2014

$823^{\prime} .914-\mathrm{dc} 23$

2014004125

A catalogue record of the book is available from the British Library.

Design by Scribe Inc.

First edition: August 2014

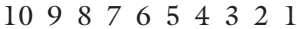




\section{Contents}

Acknowledgments vii

l Introduction 1

2 The Event of the Novel 19

3 Narrative Locations $\quad 35$

4 The Great World's New York 51

5 Narrative Space $\quad 69$

6 Distances $\quad 85$

7 The Intertextual City 101

8 Literary Space 115

9 Geographies of Creation and Promotion 129

10 Geographies of Reception $\quad 145$

11 Conclusion: What Happens Next? 163

Notes 183

Bibliography 201

Index 211 
This page intentionally left blank 


\section{ACKNOWLEDGMENTS}

As this work is a revised and expanded version of a manuscript written for Tokyo University Press, I would first like to thank my editor at TUP, Kensuke Goto, and our translator, Eimi Ozawa. I would also like to acknowledge the practical and financial support of Tokyo University Press and the University of Tokyo's Center for Pacific and American Studies.

At Palgrave Macmillan, I would like to thank Brigitte Shull, Ryan Jenkins, and the editorial and production teams.

The generous support of colleagues, staff, and graduate students at the University of Tokyo, in particular in the Department of Area Studies and in the English teaching section, has been vital to this project, and I am especially grateful to my colleagues in North American studies: Masako Notoji, Yasuo Endo, Fumiko Nishizaki, Yujin Yaguchi, and Kenryu Hashikawa. Other Tokyo colleagues I would like to thank include Izumi Hirobe, Shoko Imai, Julia Leyda, Masami Nakao, Nao Nomura, and Hatsue Shinohara; among colleagues elsewhere, I am particularly grateful to Michele Acuto, Mike Crang, James Kneale, and Angharad Saunders. Richard Carter-White heroically read and commented on both versions of the manuscript.

Personal friends-and-family thanks go especially to $\mathrm{GHH}$ and the Hones, Freegard, and Common families, to Jane and Phil Blake, Clive Collins, Dexter Da Silva, Caroline Kuroda, Graham Law, Allan Morrison, Tony Mills, Marie Plasse, Amanda Shepherd, and the inspiring Bill Vance.

Finally, the always cheerful practical and moral support of my friends Yujin and Caroline kept this book alive, as did the care and support I have received (and continue to receive) from medical professionals in Japan and the United Kingdom. I would like to thank Dr. Taiyo Kikuchi and the staff at the Mitakanomori Clinic in Tokyo, as well as Maggie Warth and the satellite unit staff at the Royal United Hospital Bath. Finally, I would like to thank my specialist at the Okubo Hospital in Tokyo, Dr. Sachiko Wakai, and her colleagues Dr. Yasutomo Abe, Dr. Ari Shimizu (now at Tokyo Women's Medical University), Dr. Hirofumi Tanii, Dr. Koji Yonekura, and the whole hospital staff. 